\title{
Functional Performance of a Manually Operated Seed Drill for Jute
}

\author{
V.B. Shambhu ${ }^{*}$ and A.K. Thakur \\ ICAR - National Institute of Research on Jute and Allied Fibre Technology, 12, Regent Park, \\ Kolkata - 700 040, West Bengal, India \\ *Corresponding author
}

\section{A B S T R A C T}

\section{Key w o r d s \\ Jute sowing, Manual seed drill, Performance \\ evaluation, Effective field \\ capacity and Seed \\ distribution efficiency \\ Article Info \\ Accepted: \\ 02 May 2018 \\ Available Online: \\ 10 June 2018}

Jute crop is one of the important cash crop grown in the south Asian countries. Among fibre crops, jute comes next to the cotton for making textile. Based on the physical and morphological characteristics of jute seed and agronomical requirement, a manually operated seed drill was designed and fabricated. Fourteen seed metering orifices are provided on each seed dispenser at equal interval of $27.4 \mathrm{~mm}$ to achieve plant to plant distance $50-70 \mathrm{~mm}$ and row spacing $250 \mathrm{~mm}$ as per the field requirement, the laboratory calibration of seed drill was performed with average seed rate of $2.39 \mathrm{~kg} / \mathrm{ha}$. No mechanical damage of the seed was observed. The field trials reveal that the seed drill was performed well and found suitable for the small and marginal jute farmers. The effective field capacity was varied from $0.162 \mathrm{ha} / \mathrm{h}$ to $0.176 \mathrm{ha} / \mathrm{h}$.

\section{Introduction}

Jute is one of the important environment friendly bast fibres and commercially grown as cash crop in the world. It is the second most important textile fibre next to cotton. Jute plays an important role in Indian economic, particularly in the eastern and north eastern states of India. It also plays a significant role in livelihood of the resource poor small and marginal farmers. In India jute is cultivated in 87 districts, mostly in the eastern parts of the country comprising West Bengal, Bihar, Assam, Orissa and eastern Uttar Pradesh. Out of 87 districts, 33 were identified as prominent jute growing district and most of them are situated in West Bengal. It is normally grown in around 8 lakh hectare in India, out of which
West Bengal alone accounts about 70 per cent of total area and about 80 percent of country's production. Jute is mostly sown at the advent of pre-monsoon showers in March and April months. It grows better in a well distributed minimum rainfall of $1200 \mathrm{~mm}$ with high temperature and high humidity during April to August. It grows well in loamy and sandy loam soil (Kundu et al., 1959; Anonymous, 1991; Anonymous, 1992; Shambhu 2014; Shambhu, 2016).

Increasing demand of jute fibre for use as soil saver, geo-textile and decorative items of handicrafts has created a need for increasing productivity as it is considered that there may not be a possibility to increase the acreage under jute. Further, availability of variety of 
jute, the pulp of which can be used in paper industry has created additional demand for increasing productivity of the crop. But, the productivity of jute is mostly stagnant. Besides biological and chemical inputs, engineering inputs are essential for increasing the jute productivity.

In traditional jute cultivation, the analysis of cost of cultivation revealed that about 38 per cent of the total cost is consumed in weeding and thinning operation while energy analysis of jute cultivation showed that about one fourth of the total energy requirement is consumed during weeding and thinning (Borkar et al., 2008; Shambhu et al., 2013; Shambhu, 2014, 2016). Farmers being poor with minimum land holding combined with almost marginal profit from jute. Thus, mechanization in jute sowing is necessary in view to reduce the overall cost of cultivation and enhance the productivity as well as production. Considering the socio- economic condition of the jute farmers and the nature of the land holding, a low cost, high field capacity and light weight manually operated jute seed-drill of three, four and five rows has been successfully designed and developed at Central Research Institute of jute and Allied Fibres (CRIJAF), Barrackpore, India. The developed jute seed drill is capable to reduce drudgery of operation and also cost of cultivation. Thus the net return of profit is increased. The small and marginal farmers are being benefited a lot using this user friendly low cost seed drill.

\section{Materials and Methods}

To design different components of the seed drill, Physical and morphological parameters/ characteristics like length, breath, thickness, bulk density, test weight and angle of repose of Corchorus olitorius (JRO-524) Jute seed were measured in the laboratory are given in the Table 1. Using these physical parameters/properties of the seed and some other agronomical information like row to row spacing, plant to pant spacing, optimum plants population per unit area etc. the dimension, shape and size of seed dispenser, capacity of seed hopper-cum-seed box and number of seed dispensing holes for seed metering were optimized. The bulk density of the seed determined the wall thickness of the seed boxcum- seed hopper. Since the shape of jute seed is irregular and having four to five faces, the shape and size of seed dispensing hole was determined by trial and error method taking seed rate into account for obtaining optimum plants population.

The average length, breadth, thickness and frontal area were found to be $2.09 \mathrm{~mm}$, $1.19 \mathrm{~mm}, 1.07 \mathrm{~mm}$ and $2.98 \mathrm{~mm}^{2}$ respectively. It was observed that bulk density, angle of repose and weight of thousand jute seeds were $742 \mathrm{~kg} / \mathrm{m}^{3}, 28.38$ degree and $1.92 \mathrm{~g}$ respectively.

\section{Description of the seed drill}

The manual jute seed drill mainly consists of seed dispenser-cum-seed box, main shaft, drive wheels-cum-transportation wheels, furrow openers and seed covering device etc. The seed dispenser (seed box) is made of MS sheet in conical section with larger side diameter of $122 \mathrm{~mm}$ and smaller side diameter of $75.5 \mathrm{~mm}$. Two bushes of bore $21.2 \varnothing \mathrm{mm}$ are provided on each side of the seed box through which main shaft passes. Shovel type furrow openers of $220 \mathrm{~mm}$ length were fitted just ahead of the seed dispenser-cum-seed box and furrow covering device as chains made up of mild steel were attached besides the seed dispenser-cum-seed box. The spacing between furrow openers is as per recommended spacing for the olitorius/tossa jute. To prevent wheel slippage in field, eight numbers of $40 \mathrm{~mm}$ long spikes were welded at equal interval on the periphery of each wheel. The 
main shaft is driven through drive wheels. Thus, the motion of the drive wheels through main shaft causes the seed dispensers (seed box) to rotate. Fourteen seed metering orifices are provided on each seed dispenser at equal interval of $27.4 \mathrm{~mm}$ to achieve plant to plant distance $50-70 \mathrm{~mm}$ in field. When seed dispenser rotates, the seeds are fallen through these orifices in the furrow made by the furrow openers. The seeds are then covered by a chain type seed covering device. The main shaft and furrow opener shaft are fitted with a rectangular frame which serves as a handle to pull the seed drill. The technical specifications of the seed drill have been presented in Table 2.

\section{Laboratory test}

Seed rate of seed drill at normal speed of sowing was calibrated as per IS 6316 test code (Anonymous, 1993). For calibration, the seed drill was jacked up and supported on its frame so that the wheels were free to rotate. A plain cloth was laid under each seed dispenser for collection of seeds. The seeds were cleaned and seed box-cum-seed dispenser of the drill was filled with cleaned seeds. The ground wheel of the drill was rotated manually for 100 revolutions at normal working speed and seed collected were weighted.

Uniform placement of seeds along the line is one of the important factors which affect the crop growth and thus the yield. Uniform placement of the seeds by the seed drills depends on their metering devices. Therefore the design of metering devices is one of the most important aspects of seed drills. Variation in dropping of seeds through different dispensers and evenness/ uniformity of seed distribution in rows were also studied as per IS 6316 test code (Anonymous, 1993). The uniformly seeds placement in the soil along the line was evaluated by using the following equation.
$S_{e}=100\left(1-\frac{d}{a}\right)$

Where,

Se $=$ seed distribution efficiency of the seeding device.

$\mathrm{d}=$ average numerical deviation of number of seeds per meter length of row from average number of seeds per meter length.

$a=$ average number of seeds per meter length of row.

Mechanical damage imparted to the seeds by the metering mechanism was also determined as per BIS test code in the laboratory.

\section{Field performance test}

Field performance tests were conducted at the ICAR-CRIJAF experiment field as per BIS test code for line sowing of jute and mustard and also at the farmers' field to evaluate the performance of seed drill for jute crop. The soil at the CRIAF experimental site was sandy loam having sand, silt and clay in the ratio of $74.80,13.30$, and 11.90 per cent respectively. The test was replicated thrice in the plot size of $50 \mathrm{~m} \times 10 \mathrm{~m}$. The field observations included speed of operation, depth of seed placement; effective field capacity, draft and mean observations were recorded. A direct reading type spring dynamometer was used to measure the pull of the seed drill. Draft of the seed drill was computed taking angle of pull into account. The power required to pull the implement was computed using the following relation.

Horse power $(\mathrm{hp})=\frac{D \times S}{75}$

Where, D = Draft of the implement, $\mathrm{kg}$

$\mathrm{S}=$ Speed of the implement, $\mathrm{m} / \mathrm{s}$ 
Labour requirement, field efficiency and power requirement were computed from the observed field data as per BIS standard. The plant physical parameters and fibre yield was compared with broadcast sowing.

The performance parameters like speed of operation, depth of seed placement, effective field capacity, field efficiency, draft force, seed distribution efficiency, plant population per square meter after emergence and fibre yield were determined. Plant population per square meter area was taken at number of places. Ease of operation and adjustment was also studied in field.

\section{Results and Discussion}

\section{Laboratory test}

\section{Calibration of seed drill}

The calibration of the seed drill was done in laboratory for jute crop. The results of the calibration are shown in the Table 3. The variation between mean discharge and seed dispensers in different rows ranged 0.40 - 3.75 per cent. This variation was acceptable within 5 percent. There was a little variation in seed rate at different seed box-cum-seed dispenser. This variation may be due to unequal size of seeds. Average seed rate was $2.39 \mathrm{~kg} / \mathrm{ha}$. This seed rate was significantly lower than the recommended seed rate of $6-7 \mathrm{~kg} / \mathrm{ha}$ for traditional practice. Thus, this reduced seed rate by more than 60 per cent may help in reducing the total cost of seeding as well as in thinning and weeding operations. Since, jute crop requires optimum plant population for better and quality fibre yield. No mechanical damage of the seed was observed.

\section{Field performance of seed drill}

The seed drill has been tested in different location with jute seed (JRO-524). The locations were CRIJAF experimental field, Singur demonstration farm and farmer's field of four districts of West Bengal. The field performance data of the seed drill are presented in Table 4. The depth of seed placement varied from $27 \mathrm{~mm}$ to $32 \mathrm{~mm}$ which could be attributed to the uniformity of soil preparation and it was with in the recommended depth of $25 \mathrm{~mm}$ to $40 \mathrm{~mm}$. The speed of operation in the field was varied from 1.91 to $2.06 \mathrm{~km} / \mathrm{h}$ with an average speed of operation was $2.0 \mathrm{~km} / \mathrm{h}$. The actual seed rate was varied from 2.50 to $2.75 \mathrm{~kg} / \mathrm{ha}$, which was significantly lower than the recommended seed rate of 6 to $7 \mathrm{~kg} / \mathrm{ha}$ in broadcasting method. Thus, this reduced seed rate by about 60 percent in field condition may help in reducing the total cost of seeding as well as the cost of cultivation by cutting labour cost in thinning and weeding operations. The seed distribution efficiency of the drill was varied from 95.24 to 99.20 per cent with an average of 96.22 per cent. It was observed that the seed distribution efficiency decreases with the increase in speed of operation, due to scattering of seeds during centrifugal discharge.

The effective field capacity was varied from $0.163 \mathrm{ha} / \mathrm{h}$ to $0.176 \mathrm{ha} / \mathrm{h}$ with an average of $0.17 \mathrm{ha} / \mathrm{h}$. The average labour requirement was only $5.87 \mathrm{man}-\mathrm{h} / \mathrm{ha}$. Draft of the machine was calculated taking height of the handle from the ground during the operation. The angle of pull was found to be $39.54^{\circ}$. The draft of the drill varied from $72.87 \mathrm{~N}$ to $78.26 \mathrm{~N}$ with an average value of $75.16 \mathrm{~N}$. The power requirement of the drill varied from $41.68 \mathrm{~W}$ to $42.68 \mathrm{~W}$ with an average of $42.35 \mathrm{~W}$, which could be easily pulled by a man for 2-3 hours continuously. The field efficiency was found to be varied from 84.97 to 90.70 with an average of 88.74 percent. Overall performance of the manually operated seed drill was found satisfactory. The seed drill in operation is shown in Figure 1 and 2. 
Table.1 Physical characteristic of Corchorus olitorius jute seed (JRO-524)

\begin{tabular}{|l|l|l|l|l|}
\hline Sl. No. & Parameters & Minimum & Maximum & A verage \\
\hline 1. & Length $(\mathrm{mm})$ & 1.803 & 2.362 & 2.09 \\
\hline 2. & Breadth $(\mathrm{mm})$ & 0.813 & 1.626 & $\mathbf{1 . 1 9}$ \\
\hline 3. & Thickness $(\mathrm{mm})$ & 0.982 & 1.105 & $\mathbf{1 . 0 7}$ \\
\hline 4. & Frontal area $\left(\mathrm{mm}^{2}\right)$ & 1.466 & 3.84 & $\mathbf{2 . 9 7 5}$ \\
\hline 5. & Weight of $1000 \mathrm{seeds}^{(\mathrm{g})}$ & $\mathbf{1 . 9 2 2}$ & \\
\hline 6. & Shape \& size of seed & Irregular shape having 4 to 5 faces with 5 to 6 angles \\
\hline 7. & Bulk density $\left(\mathrm{kg} / \mathrm{m}^{3}\right)$ & $\mathbf{7 4 2}$ & \\
\hline 8. & Angle of repose $($ degree $)$ & $\mathbf{2 8 . 3 8}$ & \\
\hline 9. & Moisture content $(\%)$ & $\mathbf{8})$ & \\
\hline 10. & Germination percent & $\mathbf{8 5}$ & \\
\hline
\end{tabular}

Table. 2 Technical specifications of the manually operated seed drill

\begin{tabular}{|l|}
\hline Parameters \\
\hline Type \\
\hline Length \\
\hline Width \\
\hline Height \\
\hline Row spacing \\
\hline Depth of sowing \\
\hline Total weight \\
\hline Number of rows \\
\hline capacity of Seed box-cum- \\
\hline seed dispenser, seed \\
\hline Seed rate \\
\hline Seed of operation \\
\hline Field capacity \\
\hline Suitability for crop \\
\hline Power source \\
\hline
\end{tabular}

\begin{tabular}{l} 
values \\
Manually operated seed drill \\
$1490 \mathrm{~mm}$ \\
$1040 \mathrm{~mm}$ \\
$350 \mathrm{~mm}$ \\
Normally $250 \mathrm{~mm}$, adjustable between $200 \mathrm{~mm}$ to $250 \mathrm{~mm}$. \\
Normally $25-50 \mathrm{~mm}$, adjustable up to $75 \mathrm{~mm}$ \\
$13.5 \mathrm{~kg}$ \\
4 \\
$455 \mathrm{~g}$ \\
2.50 to $2.75 \mathrm{~kg} / \mathrm{ha}$ \\
2.0 to $2.5 \mathrm{~km} / \mathrm{h}$ \\
0.18 to $0.20 \mathrm{ha} / \mathrm{h}$ \\
\hline Jute, Mustard and Sesame \\
Manual (one man or woman) \\
\hline
\end{tabular}

Table.3 Laboratory calibration of the seed drill for jute seed

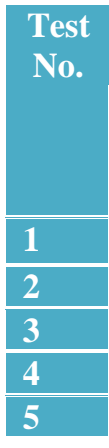

\begin{tabular}{|c|c|c|c|}
\hline \multicolumn{4}{|c|}{$\begin{array}{l}\text { Weight of seed discharge } \\
\text { in } 100 \text { revolution }\end{array}$} \\
\hline $1^{\mathrm{st}}$ & $2^{\text {nd }}$ & $3^{\text {rd }}$ & $4^{\text {th }}$ \\
\hline $\begin{array}{l}\text { row } \\
(\mathrm{g})\end{array}$ & $\begin{array}{l}\text { row } \\
(\mathrm{g})\end{array}$ & & \\
\hline 3.71 & & 3.92 & 3.9 \\
\hline .91 & & & 3.9 \\
\hline .70 & & & 3.74 \\
\hline 4.01 & 3.83 & 3.9 & 3.72 \\
\hline 3.81 & 3.71 & 3.70 & \\
\hline
\end{tabular}

\begin{tabular}{c}
$\begin{array}{c}\text { Mean } \\
\text { discharge } \\
(\mathrm{g})\end{array}$ \\
\hline 3.85 \\
\hline 3.85 \\
\hline 3.76 \\
\hline 3.87 \\
\hline 3.79 \\
\hline
\end{tabular}

\begin{tabular}{|c|}
\hline $\begin{array}{c}\text { Standard } \\
\text { deviation }\end{array}$ \\
\hline \\
\hline 0.11 \\
\hline 0.12 \\
\hline 0.07 \\
\hline 0.12 \\
\hline 0.10 \\
\hline
\end{tabular}

\begin{tabular}{|c|c|c|c|}
\hline $\begin{array}{c}\text { \% of variation from mean } \\
\text { discharge }\end{array}$ \\
\hline $\begin{array}{c}1^{\text {st }} \\
\text { row }\end{array}$ & $\begin{array}{c}2^{\text {nd }} \\
\text { row }\end{array}$ & $\begin{array}{c}3^{\text {rd }} \\
\text { row }\end{array}$ & $\begin{array}{c}4^{\text {th }} \\
\text { row }\end{array}$ \\
\hline 3.51 & 0.91 & -1.95 & -2.47 \\
\hline-1.56 & 3.90 & 1.04 & -3.38 \\
\hline 1.46 & -2.80 & 0.93 & 0.40 \\
\hline-3.75 & 0.91 & -0.91 & 3.75 \\
\hline-0.66 & 1.98 & 2.25 & -3.57 \\
\hline
\end{tabular}

\begin{tabular}{|c|c|}
\hline $\begin{array}{c}\text { Seed rate at } \\
\mathbf{2 5} \mathrm{cm} \text { row } \\
\text { to row } \\
\text { spacing } \\
\text { (kg/ha) }\end{array}$ & $\begin{array}{c}\text { Mean } \\
\text { seed rate } \\
\text { (kg/ha) }\end{array}$ \\
\hline 2.40 & 2.39 \\
\hline 2.41 & \\
\hline 2.35 & \\
\hline 2.42 & \\
\hline 2.37 & \\
\hline
\end{tabular}


Table.4 Field performance test result of the seed drill for olitorius jute in farmers' fields

\begin{tabular}{|c|c|c|}
\hline Sl.no. & Particulars & Value \\
\hline 1. & Variety & JRO -524 (Navin) \\
\hline 2. & Type of Soil & Sandy loam \\
\hline 3. & Plot size & $50 \mathrm{~m} \times 10 \mathrm{~m}$ \\
\hline 4. & Soil moisture,\% (db) & 22.75 \\
\hline 5. & Seed germination $(\%)$ & 85 \\
\hline 6. & Area of land under sowing (ha) & 0.50 \\
\hline 7. & Seed rate $(\mathrm{kg} / \mathrm{h})$ & 2.50 to 2.75 \\
\hline 8. & Row spacing (mm) & 250 \\
\hline 9. & Depth of sowing (mm) & 27-32 \\
\hline 10. & Speed of operation $(\mathrm{km} / \mathrm{h})$ & 1.91 to $2.06(2.0)$ \\
\hline 11. & Effective field / sowing capacity (ha/h) & 0.163 to $0.176(0.17)$ \\
\hline 12. & Time required (man-hr/ ha) & 5.68 to $6.13(5.87)$ \\
\hline 13. & Plant stand after emergence (plants/ sq. m) & 60 to 65 \\
\hline 15. & Draft force $(\mathrm{N})$ & 72.87 to $78.26(75.16)$ \\
\hline 16. & Field efficiency $(\%)$ & 84.97 to $90.70(88.74)$ \\
\hline 17. & Seed distribution efficiency (\%) & 95.24 to $99.20(96.22)$ \\
\hline 18. & Fibre yield, (q/ha) & 29.45 \\
\hline
\end{tabular}

Fig.1 Four-rows CRIJAF manual seed drill in sowing operation

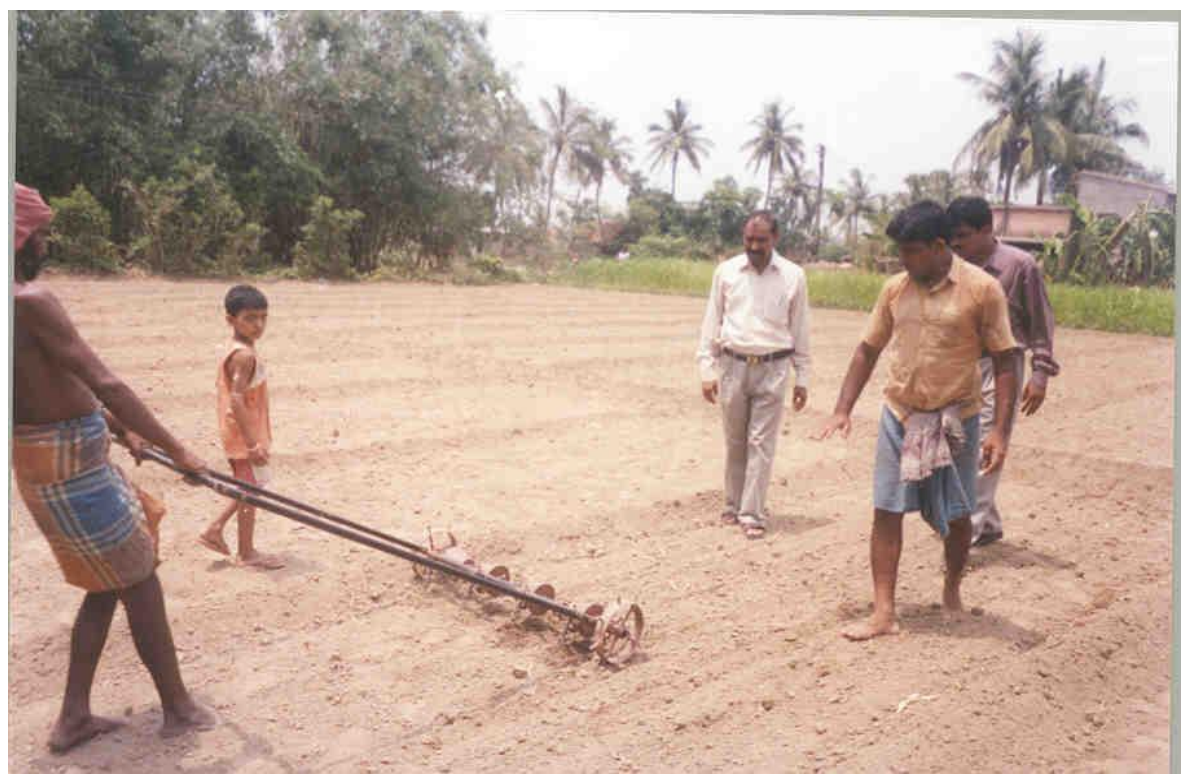


Fig.2 Four-rows CRIJAF manual seed drill in sowing operation

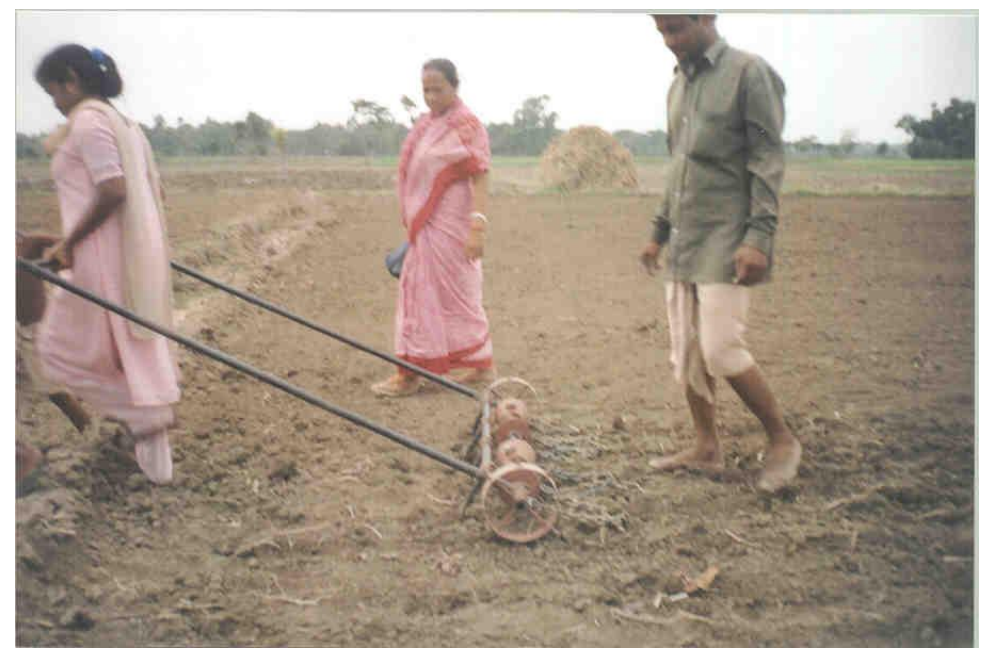

The seed distribution pattern characteristics were observed after germination of seeds under field condition, when the plant developed 2-3 leaves the plant population per square meter area was observed to be varied from 60 to 65 plants. The jute plants were harvested at 120 days after sowing (DAS) and retted in water for extraction of fibre. The fibre yield was found to be $29.45 \mathrm{q} / \mathrm{ha}$ in seed drill sown field as against $23.65 \mathrm{q} / \mathrm{ha}$ in traditional method of broadcast sowing.

In conclusion, sowing of small and tiny seeds like jute in rows is very much desirable to save seed, to reduce the cost of cultivation by cutting the cost involvement in weeding and thinning. The developed manual multi-row drill for small seeds distributed seeds uniformly along rows as well as reduced sowing cost and total cost of seeding. The average seed rate in laboratory was $2.39 \mathrm{~kg} / \mathrm{ha}$ and in the farmers' field the average seed rate was varied from 2.50 to $2.75 \mathrm{~kg} / \mathrm{ha}$. It was found that the time required in line sowing was 5 to 6 man hours per hectare which was same as compared to broadcast method which involves 5 man hours per hectare. It was also found that the cost of weeding and thinning was reduced by more than 55 per cent and increase in crop yield was found to be 18 to
24 per cent. The average plant population per square meter was 60 to 65 plants. The average effective field capacity, average field efficiency, average draft requirement and seed distribution efficiency of the seed drill was observed as $0.17 \mathrm{ha} / \mathrm{h}, 88.74$ per cent, $75.16 \mathrm{~N}$ and 96.22 per cent respectively

\section{References}

Anonymous 1991. Agricultural Machinery Design and Data Hand Book (Seeders and Planters), Economic and Social Commission for Asia and the Pacific, RNAM Bangkok.

Anonymous 1991. Proceeding and final project report of International jute organization (IJO) on jute seeder development, Dhaka, Bangladesh.

Anonymous 1992. Central Research Institute for Jute and Allied Fibres (CRIJAF) Annual report 1991-92.

Anonymous 1993. Test Code for sowing equipment seed-cum-fertilizer drill. IS: 6316. Indian Standard Institute, Manak Bhawan, New Delhi.

Borkar U N, Shambhu V B andNaik R K. 2008. Jute and allied fibre crops; energy analysis and mechanization. Jute and allied fibre updates, Central Research 
Institute for Jute and Allied Fibres, Barrackpore, Kolkata.

Kundu B C, Basak K C and Sarkar P B. 1959. Jute in India-A monograph. Indian Central Jute Committee, Calcutta. Pp. 91-92.

Shambhu V B. 2014. A Simple and low cost drill for sowing of Jute seeds. Proceedings of the All India Seminar on Appropriate Technologies of Farm Mechanization for Marginal and Small Farmers, August 08-09, 2014,
Institution of Enginees (India), Kolkata, pp. 14-18.

Shambhu V B. 2016. Energy use Pattern and Economic Analysis of Jute Production in West Bengal (India). Agricultural Mechanization in Asia, Africa and Latin America (AMA) 47(4), 74-81.

Shambhu, V. B., Nayak, L.K. and Das, Sujai 2013. Sustainable production and prospect of jute in India, COMSOMATH: Magazine on Computer Science, Social Science and Mathematics; 16(2): 29-34.

\section{How to cite this article:}

Shambhu, V.B. and Thakur, A.K. 2018. Functional Performance of a Manually Operated Seed Drill for Jute. Int.J.Curr.Microbiol.App.Sci. 7(06): 52-59.

doi: https://doi.org/10.20546/ijcmas.2018.706.008 